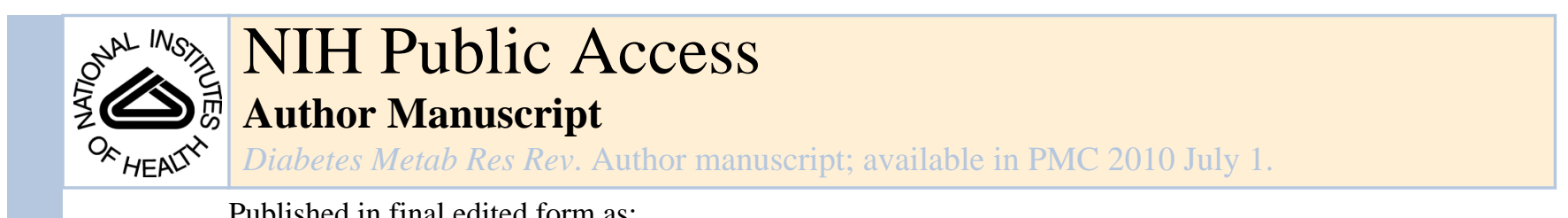

Published in final edited form as:

Diabetes Metab Res Rev. 2009 May ; 25(4): 325-328. doi:10.1002/dmrr.943.

\title{
C-peptide in the Natural History of Type 1 Diabetes
}

\author{
Jerry P. Palmer, MD \\ Department of Medicine, Department of Veterans Affairs Puget Sound Health Care System and \\ University of Washington, Seattle, WA, USA, jpp@u.washington.edu
}

\begin{abstract}
Since type 1 diabetes mellitus (T1DM) results from autoimmune damage and destruction of the pancreatic islet beta cells, a body of literature now exists describing the decline of beta cell function which occurs prior to and after the diagnosis of type 1 diabetes in humans. One of the earliest papers utilizing C-peptide to describe changes in beta cell function in type 1 diabetes patients in the time period shortly after diagnosis was published in the New England Journal of Medicine in 1973. In this paper, C-peptide was reported to increase during clinical remission and to decrease during subsequent relapse in three patients [1]. One of the first points to make is that the diagnosis of type 1 diabetes is dramatically different when made in the community, almost always due to presentations with clinical signs and symptoms of marked hyperglycemia, versus when made as part of a surveillance program of high risk non-diabetic subjects. In the DPT-1, high risk non-diabetic individuals received oral glucose tolerance tests (OGTT) every six months and in these subjects, type 1 diabetes was diagnosed in 70-75\% of patients based on the oral glucose tolerance test rather than symptoms. That is, the patients were asymptomatic with a mean fasting glucose of 115 $\mathrm{mg} / \mathrm{dL}$ and a mean two hour post prandial glucose of $278 \mathrm{mg} / \mathrm{dL}$. As shown in table 1, the C-peptide levels were much higher in subjects diagnosed by surveillance, that is in the DPT-1, compared to those diagnosed in the community. In fact, C-peptide levels in the DPT-1 patients at the time of diagnosis are closer to levels in non-diabetic control subjects than to community type 1 diabetes patients.
\end{abstract}

In the DPT-1 a confirmatory OGTT was performed subsequent to the diagnostic OGTT in addition to the oral glucose tolerance tests performed every six months over several years prior to the diagnosis of type 1 diabetes. C-peptide measured on these OGTTs have shown that the decline in C-peptide is very gradual up until six months prior to diagnosis. During the last six months prior to diagnosis, stimulated C-peptide declines more rapidly and in fact fasting C-peptide rises slightly, probably in response to the small rise in fasting glucose [2]. If the time between the initial and confirmatory diabetic OGTT's for each individual is used to calculate an immediate post-diagnosis decline in stimulated C-peptide, it is even more rapid [3] (Figure 1). This data confirms the long held clinical opinion that the decline in beta cell function is more rapid in the peri-diagnosis time period.

Another point to make regarding C-peptide and type 1 diabetes is that for many years after the diagnosis of diabetes there is much more C-peptide in many patients than commonly expected. For example, in screening type 1 diabetes patients for the DCCT, $48 \%$ of patients screened between 1-5 years after diagnosis had mixed meal tolerance test (MMTT) stimulated C-peptide levels at or above $0.2 \mathrm{nmol} / \mathrm{L}$ [4]. As will be discussed subsequently, this is the level at which clear cut advantages in terms of improved glycemic control and less hypoglycemia are seen [5]. Significant residual beta-cell function may also occur in patients with T1DM of very long duration. In the Joslin 50 year medalist study conducted by George King, all patients had a duration of type 1 diabetes of 50 years or more and many of the patients had surprisingly high C-peptide levels (personal communication). 
Another point to make is that the decline in stimulated C-peptide during the first year after the diagnosis of type 1 diabetes as reported in the literature is highly variable (Table 2). For most of these studies, the data cited in this table is from the control arm of intervention studies. In the studies describing biostator treatment and treatment with diazoxide, control patients had stimulated C-peptides at one year which were not significantly lower than at study entry [6,7]. As listed in the table, several studies have reported modest reductions at one year $[8,9,10]$ whereas other studies, including unpublished data from TrialNet, report approximately a 50\% decline in stimulated C-peptide over the first year post diagnosis [1114]. This heterogeneity in decline of C-peptide between studies and between patients is also seen within individual patients. Herold and colleagues described the decline in insulin secretion rate (ISR) in control patients from an Anti-CD3 study and commented, "Not all patients showed a persistent decline in $\beta$-cell function on all of the serial studies. Of 78 follow-up studies, 8 showed ISR AUCs that were greater than tests of the same individual at study entry(within 10 weeks post diagnosis). The improved studies occurred in 5 of 21 patients [14]." In looking at each of these reported studies carefully, I could not identify an obvious apparent cause for this marked heterogeneity.

Several factors have been proposed to affect the rate of loss of beta cell function in patients with type 1 diabetes. These factors include the age at diagnosis, degree of metabolic control, immune status based upon markers such as IL-1Ra and antibody levels, genetics including HLA, the insulin gene, and PTPN-22, and marked inter-individual variation(15-18). The DCCT conclusively showed that patients randomized to intensive glycemic control had a slower decline in stimulated C-peptide [5]. This was not a small effect. When the intensive versus conventional treatment groups were compared, the risk reduction for MMTT stimulated C-peptide to fall below the $0.2 \mathrm{nmol} / \mathrm{L}$ level was $57 \%$. On behalf of TrialNet, John Lachin and Paula McGee analyzed data from the control arms of studies worldwide in new onset type 1 diabetes patients and looked at the effect of age on rate of decline in stimulated C-peptide [4]. They found that the rate of decline in C-peptide was not different depending upon the age at diagnosis but that older patients had much higher stimulated Cpeptide levels at the time of diagnosis. Similar results were obtained by Herold and colleagues evaluating patients from the control arm of their Anti-CD3 trial [14]. But, more recent data from ongoing TrialNet new onset studies, in fact does show that younger patients have a more rapid decline in C-peptide. This issue is further complicated by how one chooses to express the data. Since there is general agreement that younger patients have lower C-peptide levels at diagnosis, if the decline post diagnosis is presented as a percentage of the C-peptide level at diagnosis, the same absolute decline will result in a greater percentage decline in younger compared to older patients who have higher C-peptide levels at diagnosis.

It is also very important to emphasize that there is clear evidence of clinical benefit resulting from preserved beta cell function in patients with type 1 diabetes. In an early DCCT paper [15], it was observed that at screening, patients with peak MMTT C-peptide levels above 0.2 $\mathrm{nmol} / \mathrm{L}$ had significantly lower hemoglobin A1C reflecting improved glycemic control by their community providers. Furthermore, after patients were enrolled in the DCCT, those with stimulated C-peptide values above $0.2 \mathrm{nmol} / \mathrm{L}$ at entry who were assigned to intensive therapy continued to have lower hemoglobin A1C levels for many years in the DCCT compared to patients with lower stimulated C-peptide levels at entry into the DCCT [5]. As expected, this improved hemoglobin A1C resulted in less retinopathy and less nephropathy and most importantly less hypoglycemia with intensive therapy $[4,5,16]$.

A final point to make is that C-peptide is usually thought of as primarily functioning to position the alpha and beta chains of insulin during insulin biosynthesis and to not have intrinsic effects as a hormone. But, there is an accumulating body of literature suggesting 
direct effects of C-peptide. These observations are both in-vitro and in clinical trials in animals and humans with type 1 diabetes. Potential direct effects of C-peptide include improving nerve conduction velocity, improving sensory and autonomic neural function, improving cardiac function, decreasing microalbuminuria, stimulating eNOS activity, inhibiting smooth muscle cell proliferation, and decreasing NF- $\kappa \beta$ signal transduction and decreasing inflammation [21-29].

In conclusion, I have tried to emphasize several "take home messages" in this review. First, a large amount of beta cell function is lost between surveillance diagnosis of type 1 diabetes and community/symptomatic diagnosis of type 1 diabetes. Second, residual beta cell function results in better glycemic control, less microvascular complications and less hypoglycemia. And consequently, marked clinical benefit might result from preserving the higher levels of C-peptide observed in patients with surveillance versus community diagnosis of type 1 diabetes. Three, the rate of beta cell loss post diagnosis is highly variable and may depend in part on the aggressiveness of the type 1 diabetes disease process. This aggressiveness may be determined by several factors including underlying genetic predisposition, age of the patient, metabolic control, and may vary within individuals over the course of their diabetes. And four, C-peptide itself may have biologic effects, most of which are proposed to be beneficial.

There are several important perspectives for future intervention studies following from these observations. First, interventions aiming at preserving residual beta-cell function are highly clinically relevant with potential impact on patient morbidity, mortality and quality of life. Second, screening by OGTT will yield populations that may benefit more than community diagnosed patients, although this remains to be shown in actual intervention studies. Third, while a low absolute residual beta-cell function at onset such as seen in children may apparently discourage inclusion of such subjects into future intervention trials, the relative rate of decline of beta-cell function may be greater after onset than generally perceived, speaking for the inclusion of such subjects and impacting power calculations of future trials related to the expected treatment effects. And fourth, clinical trials using recombinant Cpeptide are warranted.

\section{References}

1. Black MB, Rosenfield RL, Mako ME, Steiner DF, Rubenstein AH. Sequential changes in beta-cell function in insulin-treated diabetic patients assessed by c-peptide immunoreactivity. N Engl J Med. 1973; 288:1144-1148. [PubMed: 4633551]

2. Sosenko JM, Palmer JP, Greenbaum CJ, Mahon J, Cowie C, Krischer JP, Chase HP, White NH, Buckingham B, Herold KC, Cuthbertson D, Skyler JS. Diabetes Prevention Trial-1 Study Group. Patterns of metabolic progression to type 1 diabetes in the diabetes prevention trial-type 1 . Diabetes Care. 2006; 29:643-649. [PubMed: 16505520]

3. Sosenko JM, Palmer JP, Rafkin-Mervis L, Krischer JP, Cuthbertson D, Matheson D, Skyler JS. Glucose and c-peptide changes in the peri-onset period of type 1 diabetes in the diabetes prevention trial-type 1. Diabetes Care. 2008; 31:2188-2192. [PubMed: 18650369]

4. Palmer JP, Fleming GA, Greenbaum CJ, Herold KC, Jansa LD, Kolb H, Lachin JM, Polonsky KS, Pozzilli P, Skyler JS, Steffes MW. C-peptide is the appropriate outcome measure for type 1 diabetes clinical trials to preserve $\beta$-cell function. Diabetes. 2004; 53:250-264. [PubMed: 14693724]

5. The Diabetes Control and Complications Trial Research Group. Effect of intensive therapy on residual $\beta$-cell function in patients with type 1 diabetes in the diabetes control and complications trial. Ann Intern Med. 1998; 128:517-523. [PubMed: 9518395]

6. Ortqvist E, Bjork E, Wallensteen M, Ludvigsson J, Aman J, Johansson C, Forsander G, Lindgren F, Berglund L, Bengtsson M, Berne C, Persson B, Karlsson FA. Temporary preservation of $\beta$-cell function by diazoxide treatment in childhood type 1 diabetes. Diabetes Care. 2004; 27:2191-2197. [PubMed: 15333483] 
7. Shah SC, Malone JI, Simpson NE. A randomized trial of intensive insulin therapy in newly diagnosed insulin-dependent diabetes mellitus. N Engl J Med. 1989; 320:550-554. [PubMed: 2644534]

8. The Canadian-European Randomized Control Trial Group. Cyclosporin-induced remission of IDDM after early intervention. Association of $1 \mathrm{yr}$ of cyclosporin treatment with enhanced insulin secretion. Diabetes. 1988; 37:1574-1582. [PubMed: 2903105]

9. Cook JJ, Hudson I, Harrison LC, Dean B, Colman PG, Werther GA, Warne GL, Court JM. Doubleblind controlled trial of azathioprine in children with newly diagnosed type 1 diabetes. Diabetes. 1989; 38:779-783. [PubMed: 2656346]

10. Keymeulen B, Vandemeulebroucke E, Ziegler AG, Mathieu C, Kaufman L, Hale G, Gours F, Goldman M, Walter M, Candon S, Schandene L, Crenier L, De Block C, Seigneurin JM, De Pauw P, Pierard D, Weets I, Rebello P, Bird P, Berrie E, Frewin M, Waldmann H, Bach JF, Pipeleers D, Chatenoud L. Insulin needs after CD3-antibody therapy in new-onset type 1 diabetes. N Engl $\mathbf{J}$ Med. 2005; 352:2598-2608. [PubMed: 15972866]

11. Herold KC, Hagopian W, Auger JA, Poumian-Ruiz E, Taylor L, Donaldson D, Gitelman S, Harlan $\mathrm{D}, \mathrm{Xu}$ D, Zivin RA, Bluestone JA. Anti-CD3 monoclonal antibody in new-onset type 1 diabetes mellitus. N Engl J Med. 2002; 346:1692-1698. [PubMed: 12037148]

12. Herold KC, Gitelman SE, Masharani U, Hagopian W, Bisikirska B, Donaldson D, Rother K, Diamond B, Harlan DM, Bluestone JA. A single course of anti-CD3 monoclonal antibody hOKT3 gamma1 (Ala-Ala) results in improvement in c-peptide responses and clinical parameters for at least 2 years after onset of type 1 diabetes. Diabetes. 2005; 54:1763-1769. [PubMed: 15919798]

13. Brown RJ, Sinaii N, Rother K. Too much glucagon, too little insulin. Time course of pancreatic islet dysfunction in new-onset type 1 diabetes. Diabetes Care. 2008; 31:1403-1404. [PubMed: 18594062]

14. Steele C, Hagopian WA, Gitelman S, Masharani U, Cavaghan M, Rother KI, Donaldson D, Harlan DM, Bluestone J, Herold KC. Insulin secretion in type 1 diabetes. Diabetes. 2004; 53:426-433. [PubMed: 14747294]

15. Pfleger C, Mortensen HB, Hansen L, Herder C, Roep BO, Hoey H, Aanstoot H-J, Kocova M, Schloot NC. Association of IL-1ra and Adiponectin with c-peptide and remission in patients with type 1 diabetes. Diabetes. 2008; 57:929-937. [PubMed: 18299313]

16. Törn C, Landin-Olsson M, Lernmark Å, Palmer JP, Arnqvist HJ, Blohmé G, Lithner F, Littorin B, Nyström L, Scherstén B, Sundkvist G, Wibell L, Östman J. Prognostic factors for the course of $\beta$ cell function in autoimmune diabetes. J Clin Endocrinol Metab. 2000; 85:4619-4623. [PubMed: 11134117]

17. Petrone A, Galgani A, Spoletini M, Alemanno I, Di Cola S, Bassotti G, Picardi A, Manfrini S, Osborn J, Pozzilli P, Buzzetti R. Residual insulin secretion at diagnosis of type 1 diabetes is independently associated with both, age of onset and HLA genotype. Diabetes Metab Res Rev. 2005; 21:271-275. [PubMed: 15786423]

18. Petrone A, Spoletini M, Zampetti S, Capizzi M, Zavarella S, Osborn J, Pozzilli P, Buzzetti R. The PTPN22 1858T gene variant in type 1 diabetes is associated with reduced residual $\beta$-cell function and worse metabolic control. Diabetes Care. 2008; 31:1214-1218. [PubMed: 18252906]

19. The DCCT Research Group. Effects of age, duration and treatment of insulin-dependent diabetes mellitus on residual $\beta$-cell function: observations during eligibility testing for the diabetes control and complications trial (DCCT). J Clin Endocrinol Metab. 1987; 65:30-36. [PubMed: 2884229]

20. Steffes MW, Sibley S, Jackson M, Thomas W. $\beta$-cell function and the development of diabetesrelated complications in the diabetes control and complications trial. Diabetes Care. 2003; 26:832836. [PubMed: 12610045]

21. Cotter MA, Ekberg K, Wahren J, Cameron NE. Effects of proinsulin c-peptide in experimental diabetic neuropathy. Vascular actions and modulation by nitric oxide synthase inhibition. Diabetes. 2003; 52:1812-1817. [PubMed: 12829651]

22. Johansson BL, Borg K, Fernqvist-Forbes E, Kernell A, Odergren T, Wahren J. Beneficial effects of c-peptide on incipient nephropathy and neuropathy in patients with type 1 diabetes mellitus. Diabetic Medicine. 2000; 17:181-189. [PubMed: 10784221] 
23. Johansson BL, Sundell J, Ekberg K, Jonsson C, Seppanen M, Raitakari O, Luotolahti M, Nuutila P, Wahren J, Knuuti J. C-peptide improves adenosine-induced myocardial vasodilation in type 1 diabetes patients. Am J Physiol Endocrinol Metab. 2004; 286:E14-E19. [PubMed: 12954595]

24. Johansson BL, Wahren J, Pernow J. C-peptide increases forearm blood flow in patients with type 1 diabetes via a nitric oxide-dependent mechanism. Am J Physiol Endocrinol Metab. 2003; 285:E864-E870. [PubMed: 12799312]

25. Johansson BL, Borg K, Fernqvist-Forbes E, Odergren T, Remahl S, Wahren J. C-peptide improves autonomic nerve function in IDDM patients. Diabetologia. 1996; 39:687-695. [PubMed: 8781764]

26. Hansen A, Johansson BL, Wahren J, von Bibra H. C-peptide exerts beneficial effects on myocardial blood flow and function in patients with type 1 diabetes. Diabetes. 2002; 51:30773082. [PubMed: 12351450]

27. Ekberg K, Brismar T, Johansson BL, Jonsson B, Lindström P, Wahren J. Amelioration of sensory nerve dysfunction by c-peptide in patients with type 1 diabetes. Diabetes. 2003; 52:536-541. [PubMed: 12540632]

28. Luppi P, Cifarelli V, Tse H, Piganelli J, Trucco M. Human c-peptide antagonises high glucoseinduced endothelial dysfunction through the nuclear factor- $\kappa \mathrm{B}$ pathway. Diabetologia. 2008; 51:1534-1543. [PubMed: 18493738]

29. Cifarelli V, Luppi P, Tse HM, He J, Piganelli J, Trucco M. Human proinsulin c-peptide reduces high glucose-induced proliferation and NF- $\mathrm{B}$ activation in vascular smooth muscle cells. Atherosclerosis. 2008; 201:248-257. [PubMed: 18294642]

\section{Acknowledgments}

The author receives support from the following NIH grants: DK62203, DK17047, DK60155 and thanks Meron Rezene for help in preparing this manuscript. Supported (in part) by the Medical Research Service of the Department of Veteran Affairs. 


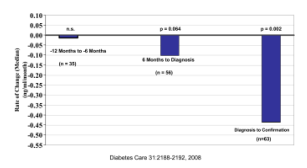

Figure 1. Rate of Change of Peak C-Peptide over Peri-Onset period Rates of change in peak C-peptide in the perionset period. Shown are the rates of change of peak C-peptide levels according to intervals before and after diagnosis. C-peptide levels changed minimally between 12 and 6 months before diagnosis. There was a decline in the 6 months before diagnosis. There was a decline in the 6 months before diagnosis that was more substantial in the period after diagnosis. 
Table 1

C-peptide at Diagnosis in DPT-1 Compared to Community

\begin{tabular}{|c|c|c|}
\hline \multicolumn{2}{|c|}{ Fasting $(\mathrm{nmol} / \mathrm{L})$} & Peak $($ nmol/L) \\
\hline Denmark ${ }^{*}$ & 0.17 & 0.27 \\
\hline DPT-1 & 0.50 & 1.3 \\
\hline Normal ${ }^{* *}$ & 0.39 & 1.81 \\
\hline
\end{tabular}


Table 2

Decline of Stimulated C-peptide During the First Year After Diagnosis of T1DM

\begin{tabular}{|l|l|l|l|l|}
\hline Author & Journal & Year & Stimulus & \% Decline \\
\hline Sosenko & Diabetes Care & 2008 & OGTT & $100 \%$ \\
\hline Shah & NEJM & 1989 & MMTT & $\uparrow$ \\
\hline Ortquist & Diabetes Care & 2004 & MMTT & NONE \\
\hline Cy A & Diabetes & 1988 & GST & $13 \%$ \\
\hline Cook & Diabetes & 1989 & MMTT & $19 \%$ \\
\hline Keymeulen & NEJM & 2005 & GST $(\uparrow g l u)$ & $24 \%$ \\
\hline Herold & Diabetes/ NEJM & $2004,05 / 02$ & MMTT & $47 \% / 58 \%$ \\
\hline Brown & Diabetes Care & 2008 & MMTT & $45 \%$ \\
\hline TrialNet & Unpub-General & MMTT & $58 \%$ \\
\hline Gottlieb & Unpub-General & MMTT & $50 \%$ \\
\hline
\end{tabular}

